\title{
The Effectiveness of D2 Serve Learning Model to Improve Students Skill in Playing Table Tennis in Medan
}

\author{
Samsuddin Siregar ${ }^{1}$ \\ \{sambatusundung@gmail.com\}
}

State University of Medan, North Sumatra, Indonesia ${ }^{1}$

\begin{abstract}
The aim of this research is to test the effectiveness of D2 Serve learning model to improve students skill in playing table tennis. The subjects of this research were the beginner students which consists of 30 students as experimental group and 30 students as control group. Quantitative approach was used in this research as the six steps (main group trials) from Research and Development design (R\&D). The type of this research is experimental research, table tennis D2Serve learning model as the treatment variable and using randomized control group pre test-post test design.Based on the data obtained from the Pre test and Post test which had given to experimental group and control group before, then the effectiveness test result of this research as follows: (1) for experimental group obtained sig (2-tailed) 0,00 smaller than 0,05 , which means there are significant differences between pre test and post test result of D2Serve learning model. As well for the control group was obtained sig value between the pre test and post test result of conventional learning model. Based on sig (2-tailed) value obtained between the two groups, it had the same high significant value. Therefore, it can be concluded that D2Serve learning model (new model) and learning model with conventional method (conventional model) together can give positive contribution in improving table tennis basic skill for beginner students. Based on statistics analysis and findings above, it can be concluded that D2Serve learning model for beginner student is worth and effective to be used as learning model which can improve drive (forehand-backhand) and serve basic technique skills in Table Tennis Sport.
\end{abstract}

Keywords: Effectiveness, model D2 Serve, skill and table tennis

\section{Introduction}

Table tennis sport is one of the compulsory subjects followed by S-1 students in Sports and Health Physical Education Study Program. Through this course, students are guided, accompanied and trained to master the basic techniques, rules, and playing techniques, in order the students have the ability and skills to play table tennis. But now, a problem rises where students' table tennis playing skill is still low. Observations had been held on the achievement of students' Tennis Table learning outcomes in the odd semester of 2015/2016 academic year, and if it is related to student passing grade competencies, it is not in the level of satisfactory category.

Tennis Table learning with its methods, models, media and materialsneeded by beginner students is a learning model which involves students more actively in the learning process, 
develops all the potentialin students selves, and accommodates the conditions and characteristics of students based on their physical and psychologically abilities in order to create a fun and an interesting learning atmosphere in accelerates the improvement of students' comprehension and skills to the material that had being taught.

In this study, the researcher developed a tennis table learning based on playing, that is the D2Serve technique model. Thislearning model is developed based on the analysis of theories which one of the theories is services, learning, and models which had been used by lecturers so far, then integrated it with playing approach. This D2Serve learning model is part oflearning model development needs to be tested for its effectiveness to see how much effectiveness level of the model is in improving the table tennis service technique skills of beginner students.

\section{Research methods}

This study deals with effectiveness of test research of D2Serve learning models in improving table

tennis basic serves skills for beginner students. The type of the research is an experimental research with randomized control group pretest-posttest design which can be described as follows:

The data are using quantitative data from observations of motion. The aim of the study is to see the level of student skills in tennis table service pouncing. The instruments used are table tennis specific test battery. The results of this studyobtained based on data analysis from the pre-test and post-test (experimental group and control group) using SPSS 17.0 for windows. The degree of significance is $\alpha=0.05$.

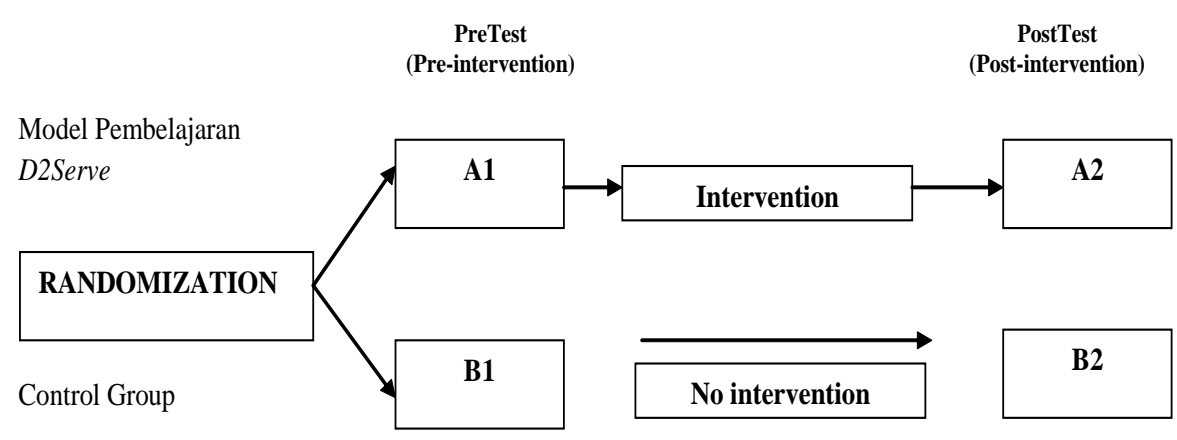

Figure 1. Research design to achieve research output

\section{Results and discussion}

There were 60 students as the sample of the D2serve model, 30 students for the experimental group and 30 students for the control group. For the research results of the effectiveness of D2serve model in improving of serve basic skills of beginner students can be known from the obtained of test and data analysis of the two groups above. For the analysis results of paired sample average differentiation (service) can be seen in table 1 and for the analysis results of Independent Samples Test can be seen in table 2. 
In this section, the analysis pattern testhad been done in testing the effectiveness of the D2Serve model on service is by using mean differentiation test (average) which analyzed by ttest (paired t-test). The calculation paired t-test is based on the data of the pre-test and post-tets values of each group, namelytable tennis learning groups by playing and table tennis learning groups by old model. For the results of the t-test calculation analysis can be seen in the following table.Based on the table 1 , it is known that the value of significance-test statistic processed by using SPSS for the new model group D2Serve is obtained sig 2-tailed 0.00 $<0.05$, which means there is a significant difference between the results of the pre-test and post-test for serve basic learning techniques based onplaying. Also for the old group conventional, it was obtained the sig 2 -tailed value is $0.00<0.05$, which means there is a significant difference between the results of the pre-test and post-test of table tennis basic learning techniques with old model conventional.

Based on the obtained of sig 2-tailed values between the two groups, both of them have a high significant value. Thus it can be concluded that service learning with D2Serve model based on playing new model and service learning with conventional learning models with conventional methods, both can contribute positively in improving thetable tennis service basic techniques skill for beginner students.

Table 1. Different analysis results of paired samples service

\begin{tabular}{lccccc}
\hline \multicolumn{2}{c}{ Service } & Mean & T & Df & $\begin{array}{c}\text { Sig } \\
\text { 2-tailed }\end{array}$ \\
\cline { 1 - 4 } New Model & Post-tets & -5.233 & -15.643 & 29 & 0.00 \\
\cline { 2 - 4 } Old Model & $\begin{array}{c}\text { Pre-tets } \\
\text { Post-tets }\end{array}$ & -4.567 & -16.921 & 29 & 0.00 \\
\cline { 2 - 3 } & Pre-tets & & & & \\
\hline
\end{tabular}

The simultaneously mean difference test between learning groups is to understand the differences of the effect of treatments in increasing treatment variables, namely service technique learning with the D2Serve model based on playing methods before and after treatment in each group. The analysis technique used is through the calculation of IBM SPSS 21.0 for Windows. For the results can be seen in the following table.

Based on table 2, it can be seen that the obtained of significance 2-tailed is 0.01 , then 0.01 $<0.05$ which means thatthere was a difference influence of the D2Serve table tennis learning model based on playing method with old conventional model exercises in improving the basicskills of table tennis services for beginner students.

Table 2. Results of independent samples test analysis

\begin{tabular}{ccccc}
\hline Servis & Df & $\begin{array}{c}\text { Mean } \\
\text { Difference }\end{array}$ & F & Sig \\
\hline $\begin{array}{c}\text { Equal variances } \\
\text { assumed }\end{array}$ & 58 & 1.400 & 2.940 & 0.01 \\
\hline
\end{tabular}


Research on the development of the D2Serve model of table tennis learning based on playing methods is conducted by researcher to help students with low basic skills especially the table tennis services basic techniques.After going through a variety of long analysis and testing processes started from needs analysis, modeling process, revision test fromexperts, field trials and model effectiveness test as the final revision phase, thus various revisions were madefor the perfection ofdevelopedproducts. The revision was carried out with various indepth studies supported by various experts, scientific concepts and theories. Based on these various processes, it can be said that some of the interesting features of this D2Serve model are:

a) The D2Serve model can improve the service basic technical skills of beginner students.

b) Beside D2Serve model can improve skills, it also can also stimulate the cognitive aspects and attitudes of students.

c) Through the D2Serve model, the learning situation brings lecturers and students more motivated and comfortable in following the table tennis learning process. This is suitable to (Xiuli Chen1, Peter Holland 1 and Joseph M Galea,2017) stated that "Physical education teachers or coaches need to create a stimulating, encouraging learning environment and to cultivate a positive approach to goal achievement in order to enable players, and in particular novice players, to learn easily, experience personal progress, and remain interested in playing tennis. Game-based teaching, adapting equipment and lessons, free expression of tactical skills rather than strict technical control, good communication, are all major factors effectively introducing the Play and Stay tennis program, which above all, stresses that the key to success with novice players is to get them playing tennis from the very first lesson ".

d) Through the D2Serve model, it canstimulate collaboration between students groups to be more synergistic in doing the task of motion which is given by the lecturer.

e) This model also can enrich the scientific repertoire of lecturers who are struggling with table tennis learning.

Furthermore, various learningin the D2Serve model as theresearch development products has a simpler procedure and the beginner students as direct users of this product will be easier to adapt on the various basic service skill motion tasks exist in each variation. Each variation also contains the principle of learning that is adapted to the principle concept of motion learning, namely the stages of motion in each variation starts from an easy phase to difficult phase which is more complex. Thus, with this concept it will be easier for users of this model to master service techniques correctly.

\section{Conclusion}

Based on the research result and discussion have been explained previously, conclusions can be drawn that is D2Serve learning model can improve the service skills of beginner students, thus the D2Serve learning model deserves to be used as a learning modelby lecturers and teachers in the table tennis course learning process.

\section{References}

[1] Borg. W. R.,Gall, M. D.:. Education Research: And Introduktion, Fifh education. NewYork: Long (1989)

[2] Cherly A. Coker.:. .Motor Learning And Control Practitioners. New Mexico:Mcgrawhill (2003)

[3] Hanif A. Sofyan.:. Model Pembelajaran Permainan Tenis Meja. PT.Bumi Timur Jaya. Jakarta (2011) 
[4] Mc.Afee Richard.: Table Tennis:Steps To Success.Canada.Human Kinetics,Inc (2009)

[5] Peter Simpson.: Teknik Bermain Pingpong. Pionir Jaya. Bandung (2007)

[6] Rusman.:. Model-Model Pembelajaran. Jakarta. PT.RajaGrafindoPersada (2012)

[7] Schmidt, Richard A.: Motor Learning And Performance From Principle Into Practice. Human Kinetics. Champaign, IL. (1991)

[8] Tite Juliantine.: Model-model pembelajaran dalam pendidikan jasmani. CV.Bintang Warli Artika. Jakarta (2013) 